\title{
FAKTOR-FAKTOR YANG MEMPENGARUHI PENINGKATAN MUTU PENDIDIKAN DI KAMPUS STIA ALAZKA AMBON
}

\author{
Suleman Angkotasan, Soleman Watianan \\ Program Studi Sosiologi Fakultas Ilmu Sosial dan Ilmu Politik \\ Universitas Pattimura \\ suleman19mei62@gmail.com
}

\begin{abstract}
Abstrak
Undang-undang nomor 20 tahun 2003 tentang sistem pendidikan nasional bahwa pendidikan nasional berfungsi untuk mengembangkan kemampuan dan membentuk watak serta peradaban bangsa yang bermartabat dalam rangka mencerdaskan kehidupan bangsa. Namun pula, dalam lembaga pendidikan ditemukan berbagai kendala yang mengganggu jalannya proses untuk mencapai mutu pendidikan sebagaimana yang di jumpai pada kampus STIA Abdul Aziz Kataloka Ambon yang mana belum optimalnya upaya peningkatan mutu pendidikan di kampus. Berbagai hal yang menjadi penghambat belum optimalnya peningkatan mutu pendidikan antara lain: (1) sistem manajemen yang tidak berjalan dengan baik, (2) ketidak sesuaian kurikulum yang ada dengan tuntutan kebutuhan kekinian, (3) kwalitas tenaga pendidik yang belum memadai, (4) kurangnya kedisiplinan mahasiswa, (5) serta kurang adanya kerjasama dan kekompakan antara dosen dan pegawainya. Dalam kondisi yang demikian ini dibutuhkan peran aktif pimpinan dalam mereformasi serta menata ulang sistem yang ada sehingga diharapkan terjadi perubahan kedepannya.
\end{abstract}

Kata Kunci: Pendidikan, Mutu Pendidikan, Faktor yang Mempengaruhi, STIA Alazka

\begin{abstract}
Law number 20 of 2003 concerning the national education system states that national education functions to develop capabilities and shape the character and civilization of a dignified nation in the context of the intellectual life of the nation. However, various obstacles were found in educational institutions that interfered with the process to achieve the quality of education, as seen at STIA Abdul Aziz Kataloka Ambon, where efforts to improve the quality of education on campus were not optimal. Various things that hinder the improvement of the quality of education are not yet optimal because: (1) the management system is not working well, (2) the existing curriculum is not following the demands of contemporary needs, (3) the quality of the teaching staff is not adequate, (4) lack of student discipline, (5) lack of cooperation and cohesiveness between lecturers and employees. In such conditions, an active leadership role is needed in reforming and rearranging the system so that changes are expected in the future.
\end{abstract}

Keywords: Education, Quality of Education, Influencing Factors, STIA Alazka 


\section{Pendahuluan.}

Di era yang serba modern ini, setiap negara akan mengalami kemajuan di segala aspek kehidupan. Efek yang ditimbulkan diantaranya kebutuhan masyarakat akan mengalami pergeseran dari sederhana menjadi modern. Kebutuhan tersebut hanya dapat dipenuhi melalui pendidikan. Pernyataan tersebut memaksa kita untuk senantiasa meningkatkan mutu pendidikan di Indonesia. Dalam sistem Pendidikan Nasional adalah keseluruhan komponen pendidikan yang saling terkait secara terpadu untuk mencapai tujuan pendidikan nasional.

Tuntunan atau mutu pendidikan menimbulkan banyak masalah yang terkait diantaranya: Terbatasnya anggaran pendidikan, manajemen pengelolaan pendidikan dan tata kelola yang baik untuk mewujudkan good governance. Untuk dapat menjalankan peran sebagai pengawal budaya akademik dan ilmiah, perguruan tinggi berbentuk lembaga independen dengan tata kelola yang berbasis otonomi yang sesuai undangundang nomor 12 tahun 2012 tentang pendidikan tinggi. Tata kelola perguruan tinggi mampu memberikan kebebasan akademik dan ilmiah bagi civitas akademik nya sehingga mereka mampu berkembang secara maksimal menjadi akademisi Dan ilmuwan unggulan.

Berdasarkan undang-undang nomor 20 tahun 2003 tentang pendidikan nasional bahwa pendidikan nasional berfungsi untuk mengembangkan kemampuan dan membentuk watak serta peradaban bangsa yang bermartabat dalam rangka mencerdaskan kehidupan bangsa, bertujuan untuk mengembangkan potensi peserta didik agar menjadi manusia yang beriman dan bertakwa kepada Tuhan Yang Maha Esa, berakhlak mulia, sehat, cakap, kreatif, Mandiri dan menjadi warga negara yang demokratis.

Mahasiswa merupakan individu yang mempunyai potensi dan bakat yang perlu dimantapkan. Melalui Pendidikan, potensi yang ada pada diri mahasiswa dapat senantiasa ditumbuhkembangkan ke arah yang positif. Untuk mencapai hal itu, dosen sangat berperan penting dalam menumbuhkembangkan potensi tersebut, karena dosen merupakan individu yang di setiap harinya bersentuhan langsung dengan mahasiswa. Dosen harus Dapat mengidentifikasi dan membantu menyelesaikan berbagai macam permasalahan dan kesulitan dalam proses belajar yang dialami mahasiswa, sehingga dapat meningkatkan prestasi belajar mahasiswa. Menurut Miarso (2004: 12) mengatakan bahwa efektivitas belajar mengajar adalah ukuran keberhasilan dari suatu proses interaksi antara peserta didik maupun dengan pendidik dalam situasi edukatif untuk mencapai tujuan pembelajaran. 
Berkaitan dengan itu di wilayah Kota Ambon yang merupakan ibukota provinsi Maluku di Negara Republik Indonesia yang memiliki kepadatan penduduk semakin berkembang dengan mobilitas masyarakat yang juga kian meningkat dalam aktivitas sehari-harinya sehingga menjadi suatu faktor penting dalam pertumbuhan sektor politik, ekonomi, sosial budaya dan pertahanan keamanan yang dapat dirasakan karena pertumbuhan sektor-sektor tersebut semakin berkembang sehingga secara langsung diperlukan adanya peningkatan mutu pendidikan sebagaimana mempunyai peranan yang sangat penting dan strategis yang hendak diperhatikan dengan baik sehingga bisa menghasilkan sumber daya yang berkompetensi sesuai dengan bidangnya termasuk pada lembaga pendidikan STIA Abdul Aziz Kataloka Ambon yang merupakan salah satu lembaga pendidikan swasta yang memiliki tujuan peningkatan akses bidang ilmu administrasi dan kebijakan publik yang dapat diwujudkan melalui peningkatan mutu pendidikan agar dapat mengurangi tingkat pergeseran paradigma masyarakat yang dalam di era globalisasi dewasa saat ini.

Dalam melakukan peningkatan pendidik yang bermutu adalah melalui pendidikan yang mampu menghasilkan lulusan yang memiliki kemampuan atau kompetensi, baik kompetensi akademik maupun kompetensi kejuruan, yang didasari oleh kompetensi personal dan sosial, serta nilai-nilai akhlak mulia, yang keseluruhannya merupakan kecakapan hidup (life skill). (Sudradjat (2005:17).

Undang-Undang RI Nomor 20 tahun 2003 tentang Sistem Pendidikan Nasional (Sisdiknas), pasal 1 dan 4 yaitu pendidikan adalah usaha sadar dan terencana untuk mewujudkan suasana belajar dan proses pembelajaran agar peserta didik secara aktif mengembangkan potensi dirinya untuk memiliki kekuatan spiritual, pengendalian diri, kepribadian, kecerdasan, akhlak mulia, serta keterampilan yang diperlukan oleh dirinya, bangsa maupun Negara.

Olehnya itu, sebagai upaya yang dapat dilakukan lembaga pendidikan STIA Abdul Aziz Kataloka Ambon sesuai tuntutan Tridharma perguruan tinggi yaitu pendidikan, penelitian dan pengabdian pada masyarakat sehingga dapat meningkatkan proses belajar mengajar di kampus agar mampu menciptakan lulusan yang kompeten dalam bidang ilmu administrasi kebijakan publik yang berbasis laut Pulau. Selain itu kegiatan kerjasama dapat dilakukan dengan pihak-pihak terkait, guna mendapatkan hasil yang lebih maksimal melalui beberapa peran yang berbeda namun terkait di dalamnya. 
Oleh kerena itu, seluruh komponen civitas akademik terus berupaya untuk melaksanakan berbagai bentuk kegiatan termasuk melakukan kerjasama civitas akademika dan instansi lain melakukan proses belajar mengajar, melakukan berbagai penelitian serta melakukan berbagai pengabdian pada masyarakat guna untuk meningkatkan mutu pendidikan yang berkualitas dan menghasilkan sumber daya yang handal dan berdaya saing yang sesuai dengan tantangan zaman yang dihadapi saat ini.

Namun jika dicermati langsung dilapangan ditemukan fenomena-fenomena yang dijumpai pada kampus STIA Abdul Aziz Kataloka Ambon mengenai belum optimalnya peningkatan mutu pendidikan di kampus yang tampak terlihat sebagai berikut rendahnya keaktifan dan kehadiran peserta didik di kampus, rendahnya prestasi belajar peserta didik di kampus, rendahnya kehadiran pegawai di kantor pada saat jam kerja, kurangnya keterampilan kerja pegawai dalam mengelola mesin elektronik, terbatasnya tenaga administrasi yang menyebabkan rendahnya kualitas pelayanan bagi mahasiswa

\section{Metode Penelitian.}

Penelitian ini melakukan pendekatan kualitatif. Penelitian berlangsung pada Kampus STIA Alazka Ambon dengan metode pengambilan data melalui wawancara dan observasi. Informan sebanyak 15 orang yang terdiri dari unsur mahasiswa, tenaga dosen dan tenaga kependidikan.

\section{Temuan dan Pembahasan.}

Sekolah Tinggi Ilmu Administrasi Abdul Aziz Kataloka (STIA ALAZKA) Ambon yang merupakan salah satu perguruan tinggi swasta di Maluku yang berdiri pada tahun 2001 yang ditandai dengan diterbitkannya Surat Keputusan Mentri Pendidikan Nasional Repblik Indonesia Nomor : 201/D/0/2001 tanggal 26 September 2001 tentang Pemberian Ijin Penyelenggaraan Program Studi dan Pendirian Sekolah Tinggi Ilmu Administrasi (STIA) Abdul Aziz Kataloka Ambon. Sekolah Tinggi Ilmu Administrasi Abdul Aziz Kataloka hingga kini memiliki 31 dosen dan pegawainya yang diantaranya terdiri dari 22 anggotanya adalah laki-laki dan 9 anggotanya adalah perempuan.

Perguruan ini senantiasa berupaya untuk meningkatkan mutu mahasiswanya. Mahasiswa harus menjadi insan akademis yang intelek, berkepribadian baik, berpegang teguh pada nilai-nilai keagamaan dan berjiwa sosial yang tinggi. Hal itu sebagai bekal 
bagi mahasiswa untuk mempersiapkan diri terjun di dunia kerja maupun di lingkungan masyarakat. Cara yang dapat ditempuh untuk mencetak lulusan yang mampu terjun dalam dunia kerja dan lingkungan masyarakat adalah salah satunya meningkatkan prestasi belajar mahasiswa.

Dalam sebuah lembaga pendidikan tinggi, banyak faktor-faktor yang mengganggu jalannya proses pendidikan sehingga dapat mempengaruhi peningkatan mutu pendidikan. Setelah dilakukaknnya penelitian di kampus STIA Abdul Aziz Kataloka Ambon, peneliti menemuhan berbagai faktor-faktor dan permasalahan-permasalahan yang terjadi diantaranya sebagai berikut: 1 . Kurangnya kehadiran pimpinan dikantor sehingga dalam pelaksanaan pengambilan kebijakan terhadap dosen dan pegawai sedikit lambat meskipun dapat diselesaikan dengan baik. Selain itu kurangnya ketegasan sikap pimpinan mengenai pembayaran uang semester agar tidak berdampak pada pembiayaan fasilitas dikantor serta kebutuhan kegiatan pelatihan dosen dan pegawai guna memperlancar proses pelayanan untuk meningkatkan mutu pendidik diperguruan tinggi. 2. Kuruikulum yang digunakan saat ini sudah sesuai standar nasional dengan tujuan untuk menghasilkan lulusan yang kompeten dan berdaya saing dalam pasar kerja. Begitupula materi perkuliahan yang disampaikan dosen kepada mahasiswa agar dapat disesuaikan dengan kurikulum yang berlaku. 3. Pendidik yang kurang kompeten sehingga dijumpai Hanya beberapa tenaga pendidik yang menyiapkan satuan cara pembelajaran (SAP) dan GBPP sebagai panduan pembelajaran, dijumpai juga terdapat dosen yang memberikan perkuliahan tidak menggunakan alat peraga seperti laptop, LCD. Dan alat bantu lainnya. 4. Tenaga kependidikan yang mengalami beberapa kendala berupa keterlambatan pada jam masuk kantor dan pulang kantor, kurangnya kesetiaan tenaga kependidikan terhadap pekerjaan, sikap tenaga kependidikan yang terkesan kurang baik, skill yang dimiliki tenaga kependidikan yang masih kurang terutama mengenai keterampilan dalam mengelola komputer. 5. Kurangnya keaktifan dan kehadiran mahasiswa dalam mengikuti proses belajar mengajar, serta rendahnya tingkat kehadiran mahasiswa di kampus untuk melakukan pengurusan administrasi di kantor. 6. Kurangnya kerjasama antara dosen dan pegawai dalam pelaksanaan pekerjaan dan kegiatan tertentu sehingga dapat melibatkan pimpinan terutama dalam penyelesaiannya, juga kurangnya tingkat kerjasama lembaga pendidikan tinggi dengan instansi lain yang terlihat sebagai instansi terkait berhasil memberikan bantuan fasilitas kepada kampus, sedangkan yang lainnya sebatas kegiatan 
sosialisasi. Selain itu kurangnya kegiatan kerjasama yang melibatkan dosen dan mahasiswa berupa penelitian bersama, serta kegiatan pengabdian masyarakat.

Berdasarkan data yang telah diperoleh terlihat jelas bahwa untuk meningkatkan mutu pendidikan pada perguruan tinggi termasuk di kampus stia Abdul Azis kataloka Ambon sangat ditentukan oleh beberapa faktor, menurut hadis dan Nurhayati (2010: 3) menyatakan bahwa dalam perspektif makro banyak yang mempengaruhi mutu pendidikan diantaranya faktor kurikulum, kebijakan pendidikan, fasilitas pendidikan, aplikasi teknologi informasi dan komunikasi dalam dunia pendidikan khususnya dalam kegiatan proses belajar mengajar, aplikasi metode strategi dan pendekatan pendidikan yang mutakhir dan modern, metode evaluasi pendidikan yang tepat, biaya pendidikan yang memadai, manajemen pendidikan yang dilaksanakan secara profesional, sumber daya manusia para pelaku pendidikan yang terlatih, berpengetahuan, berpengalaman dan profesional.

Selain itu, dalam kajian Departemen Agama ( 2004: 13) mengemukakan bahwa faktor yang mempengaruhi mutu pendidikan tinggi yaitu : (1) manajemen dan kepemimpinan, (2) kurikulum,(3) dosen,(4) proses belajar mengajar, (5) input mahasiswa, (6) fasilitas belajar, (7) lingkungan belajar, (8) dana operasional, (9) kemampuan dosen dalam melakukan penelitian ilmiah, (10) kemampuan dosen dalam menulis laporan penelitian atau artikel yang berdasarkan hasil penelitian yang menarik, (11) perhatian pimpinan untuk menyebarluaskan hasil penelitian yang telah di lakukan oleh dosen dan mahasiswanya.

Dalam upaya untuk mewujudkan uraian tersebut, maka Pimpinan dan civitas akademika dapat memberikan prioritas yang cukup tinggi di perguruan tinggi melalui program pengembangan pendidikan yang direncanakan dan dilaksanakan secara bertahap, mulai dari tingkat kepemimpinan, tenaga pengajar, peserta didik kurikulum dan kerjasama untuk mewujudkan pembangunan guna meningkatan kualitas dan kuantitas sarana dan prasarana pendidikan.

Di sisi lain, faktor yang mempengaruhi mutu pendidikan secara umum menurut Edward sallis (1984) menyebutkan bahwa kondisi yang menyebabkan rendahnya mutu pendidikan dapat berasal dari berbagai macam sumber yaitu miskinnya perancangan kurikulum, ketidakcocokan pengelolaan gedung, lingkungan kerja yang tidak kondusif, 
ketidak sesuaian sistem dan prosedur (manajemen), tidak cukup nya jam pelajaran, kurangnya sumber daya, dan pengadaan staf.

Dengan demikian perlunya Berbagai upaya dan kebijakan pimpinan dalam peningkatan mutu pendidikan di perguruan tinggi di mana merupakan urgensi yang mendesak untuk segera dilakukan perbaikan. Peningkatan mutu itu pada dasarnya dapat dilakukan dengan strategi merubah salah satu dari subsistem : Manusia dan teknologi meliputi : (1) mahasiswa yang dididik, (2) dosen sebagai pendidik dan pengajar, (3) sarana dan prasarana, (4) kurikulum akademik, (5) kerjasama di berbagai bidang, dan (6) proses organisasi, sehingga pendidikan tinggi dan dunia kerja dapat menjadi fokus yang penting untuk mewujudkan nya melalui kerjasama dengan banyak pihak ungkapkan lulusan yang bermutu di perguruan tinggi.

\section{Kesimpulan.}

Berdasarkan Pembahasan yang dikemukakan terhadap faktor-faktor yang mempengaruhi peningkatan mutu pendidikan di kampus STIA Abdul Azis kataloka, maka disampaikani kesimpulan sebagai berikut:

1. Kepemimpinan yaitu masih kurangnya kehadiran pemimpin di kantor Sehingga dalam pelaksanaan pengambilan kebijakan terhadap dosen dan pegawai sedikit lambat meskipun dapat diselesaikan dengan baik. Selain itu kurangnya ketegasan sikap pimpinan Mengenai pembayaran uang semester mahasiswa yang seharusnya mahasiswa melakukan pembayaran uang semester dengan tepat waktu sehingga berdampak pada pembiayaan fasilitas di kantor serta kebutuhan kegiatan pelatihan dosen dan pegawai guna memperlancar proses pelayanan untuk meningkatkan mutu pendidikan di perguruan tinggi.

2. Kurikulum yaitu kurikulum yang digunakan saat ini sudah sesuai standar nasional dengan tujuan untuk menghasilkan lulusan yang berkompeten dan berdaya saing tinggi dalam pasar kerja. Olehnya itu, berbagai upaya telah dilakukan oleh pimpinan guna mewujudkan perguruan tinggi yang sehat dan menciptakan lulusan yang handal, kurikulum merupakan faktor penting yang harus dilakukan melalui perubahan dan pengembangan sesuai kebutuhan pasar kerja. Begitu pula materi perkuliahan yang disampaikan oleh dosen kepada mahasiswa agar dapat disesuaikan dengan kurikulum yang berlaku khususnya di kampus saat ini guna mewujudkan peningkatan mutu pendidikan perguruan tinggi 
3. Tenaga pendidik (dosen) yaitu menunjukkan hanya sebagian dosen yang menyiapkan satuan cara pembelajaran (SAP) dan GBPP Sebagai panduan pembelajaran, dijumpai pula terdapat dosen yang memberikan perkuliahan tidak menggunakan alat peraga seperti laptop, LCD, dan alat bantu lainnya. Tingkat kehadiran dosen di kelas ditemukan adanya Pembagian waktu tatap muka dalam proses perkuliahan minimal 16 kali tatap muka dalam satu semester berjalan, hal ini juga tergantung dari pada tingkat kehadiran dosen pada waktu masuk dan pulang kantor yang terlihat bahwa kehadiran tersebut dilakukan tergantung pada jam perkuliahan berjalan.

4. Tenaga kependidikan ( pegawai) yaitu menunjukkan masih terdapat kendala yang dihadapi oleh tenaga kependidikan berupa keterlambatan pada jam masuk kantor dan pulang kantor, kesetiaan tenaga kependidikan terhadap pekerjaan yang masih kurang meskipun akibat dari gangguan teknis, sikap tenaga kependidikan yang sebagian menunjukkan kurang baik mengenai pelayanan kepada yang datang melakukan pengurusan di kantor serta kemampuan atau skill yang dimiliki tenaga kependidikan yang masih kurang terutama mengenai keterampilan dalam mengelola komputer.

5. Peserta didik (mahasiswa) yaitu masih rendahnya keaktifan dan kehadiran mahasiswa dalam mengikuti proses belajar mengajar, serta rendahnya tingkat kehadiran mahasiswa di kampus untuk melakukan pengurusan mengenai proses administrasi di kantor. Olehnya itu adanya berbagai upaya lembaga pendidikan untuk dorong meningkatkan keaktifan dan kehadiran mahasiswa di kampus melalui berbagai kebijakan atau kesediaan fasilitas yang memadai sehingga mahasiswa selalu hadir dan aktif untuk mengikuti berbagai bentuk kegiatan kegiatan kampus agar dapat mewujudkan peningkatan mutu pendidikan.

6. Jaringan kerjasama yaitu menunjukkan masih kurangnya kerjasama antara dosen dan pegawai dalam melaksanakan pekerjaan dan kegiatan tertentu sehingga dapat melibatkan pimpinan terutama dalam penyelesaiannya, juga kurangnya tingkat kerjasama lembaga pendidikan tinggi dengan instansi lain yang terlihat sebagian instansi terkait berhasil memberikan bantuan fasilitas kepada kampus sedangkan lainnya sebatas kegiatan-kegiatan sosialisasi, Selain itu kurangnya kegiatan kerjasama yang melibatkan dosen dan mahasiswa berupa penelitian bersama, ekstrakurikuler dan kegiatan pengabdian kepada masyarakat, dikarenakan kegiatan-kegiatan tersebut hanya dapat dilakukan di waktu-waktu tertentu saja, begitu pula menunjukkan masih kurangnya kerjasama 
pimpinan dan bawahan yang terlihat seperti kegiatan akreditasi kedua program studi, di mana hanya Program Studi Ilmu Administrasi Publik yang dapat mencapai target nilai yang memuaskan sedangkan program studi administrasi bisnis belum memiliki nilai yang memuaskan terutama pada lulusan program studi tersebut.

\section{Daftar Pustaka.}

Hendyat Soetopo, 2005. Pendidikan dan Pembelajaran, Cet: I, UMM Malang : Malang.

Hadis Abdul dan Nurhayati, 2010. Menejemen Mutu Pendidikan, Alfabeta : Bandung.

Moch Idochi Anwar. 2013. Administrasi Pendidikan dan Menejemen Biaya Pendidikan, Rajagrafindo Persada. Jakarta.

Nur Zazin. 2011. Gerakan Menata Mutu Pendidikan: Teori \& Aplikasi. Ar-Ruzz Media : Yogyakarta

Sagala, Syaiful. 2003. Menejemen Berbasis Sekolah dan Masyarakat. Alfabeta : Bandung.

Susanti, Tris. 2013. Pentingnya MSDM Dalam Meningkatkan Kualitas Pendidikan, (http://www.hrcentro.com, diakses pada tanggal 30 Juni 2021).

Subagio Atmodiwirio, 2002. Menejemen Pendidikan Indonesia, Ardadizya Jaya: Jakarta

Usman, Husaini. 2006. Menejemen Teori, Praktek dan Riset Pendidikan, Bumi Aksara : Jakarta.

Yosal Iriantara, 2005. Terjemahan Pendidikan Berbasis Mutu, Cet : I, Pustaka Belajar : Yogyakarta. 